\title{
Effect of posture on blood pressure in the elderly
}

\author{
F. I. Caird, G. R. Andrews, and R. D. Kennedy \\ From the Department of Geriatric Medicine, University of Glasgow
}

The blood pressure was measured in the lying position and after I minute's quiet standing in 494 people aged 65 or more living at home. A drop of $20 \mathrm{mmHg}$ or more in systolic pressure occurred on standing in 24 per cent, of $30 \mathrm{mmHg}$ or more in 9 per cent, and of $40 \mathrm{mmHg}$ or more in 5 per cent. The frequency of a fall on standing increased with age.

Comparison between subjects whose pressure fell on standing and those in whom it did not showed that there was no significant difference in the frequency of various factors (organic brain disease, heart disease, absent ankle jerks, varicose veins, anaemia, urinary infection, a low serum sodium concentration, or the taking of potentially hypotensive drugs) taken singly, but that two or more of these factors were more often present in those whose pressure fell on standing.

Orthostatic hypotension is a common phenomenon in the elderly, and is frequently considered to be a cause of symptoms. A fall in systolic pressure on standing of $200 \mathrm{mmHg}$ or more was found in II per cent of 250 reasonably healthy old people (Rodstein and Zeman, 1957), and in 17 of 100 elderly patients in hospital (Johnson et al., 1965). A fall of $40 \mathrm{mmHg}$ or more was found in 4 to 5 per cent in both studies.

Several factors may be involved in the production of orthostatic hypotension in the elderly, including acute infections, reduction in blood volume or cardiac output, varicose veins (Rodstein and Zeman, 1957), hyponatraemia (Fine, 1969), a wide variety of commonly prescribed drugs (Barraclough and Sharpey-Schafer, 1963), and disorders of the neurological mechanisms which normally prevent or limit a fall in blood pressure on standing (Johnson et al., 1965).

The present study, which is part of a detailed clinical, laboratory, psychiatric, and social survey of old people living at home, was designed to investigate the frequency of orthostatic hypotension in the elderly and the factors associated with it.

\section{Methods}

Two stratified random samples of people aged 65 or more and living at home were drawn, the first from the whole elderly population of the town of Kilsyth (Andrews, Cowan, and Anderson, 1971), and the second from six general practices in northern Glasgow. The stratification procedure was designed to increase the

Received 9 November 1972. proportion of people aged over 75. People resident in institutions were not considered, nor those acutely ill at the time they were approached. The surveys continued until 201 people from Kilsyth and 300 from northern Glasgow had taken part. The findings in the two surveys were virtually identical, and they have therefore been combined for the purposes of this study.

A medical history, including a detailed record of drugs currently being taken, and supplemented where appropriate by reference to general practitioner or hospital records, was taken from each participant, and a full clinical examination carried out. The blood pressure was recorded in the lying position, and after approximately $I$ minute's quiet standing, within 2 hours of mid-day. Investigations carried out included the following: estimation of haemoglobin and serum electrolytes, a 13-lead electrocardiogram, and a bacterial count on a clean specimen of urine.

Organic brain disease was considered present if there was evidence of focal or diffuse brain disorder, or of Parkinsonism. Ischaemic heart disease was diagnosed when there was a standard history of angina pectoris (Rose and Blackburn, 1968), and/or $Q$ wave abnormalities on the electrocardiogram codable under the Minnesota code (Rose and Blackburn, 1968; Kennedy and Caird, 1972). The following groups of drugs were considered capable of producing orthostatic hypotension: ganglion-blockers, sympatholytic drugs, methyldopa, oral diuretics, phenothiazines, antihistamines, tricyclic antidepressants, diazepam and related compounds, barbiturates, and anticholinergic drugs. Anaemia was considered present if the haemglobin concentration was less than $12 \mathrm{~g} / 100 \mathrm{ml}$ and urinary infection if there was a bacterial count of 100,000 per $\mathrm{ml}$ of organisms of one species (Akhtar et al., 1972). Note was taken of those whose serum sodium concentration was $137 \mathrm{mMol} / \mathrm{l}$. or less. 
TABLE I Frequency of drop in systolic blood pressure on standing in relation to age and sex

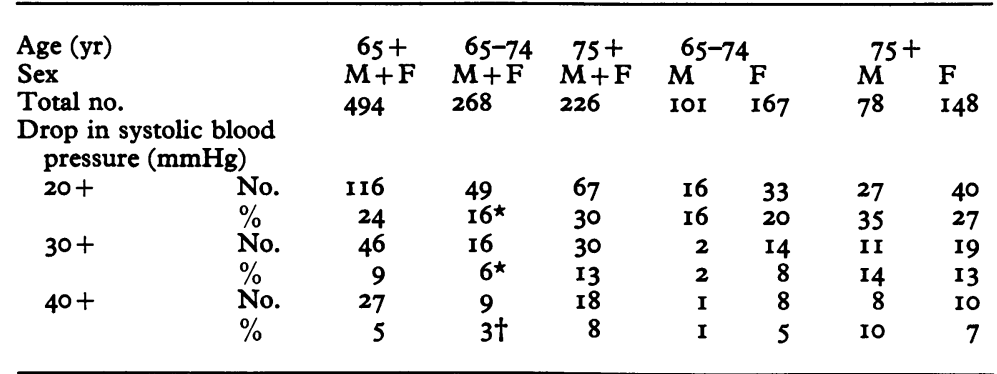

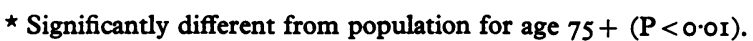

$\dagger$ Significantly different from population for age $75+(P<0.05)$.

\section{Results}

The lying and standing blood pressures were recorded in 494 subjects $(98.5 \%$ of the total). The systolic pressure fell by $20 \mathrm{mmHg}$ or more in 116 (24\%) (Table I). Of these, it fell by $30 \mathrm{mmHg}$ or more in $46(9 \%$ of the total). It fell by $40 \mathrm{mmHg}$ or more in $27(5 \%)$ of the total. There was no sex difference, but falls in systolic pressure of all three magnitudes were significantly commoner in those over 75 than in those under that age (Table $I$; Fig. I).

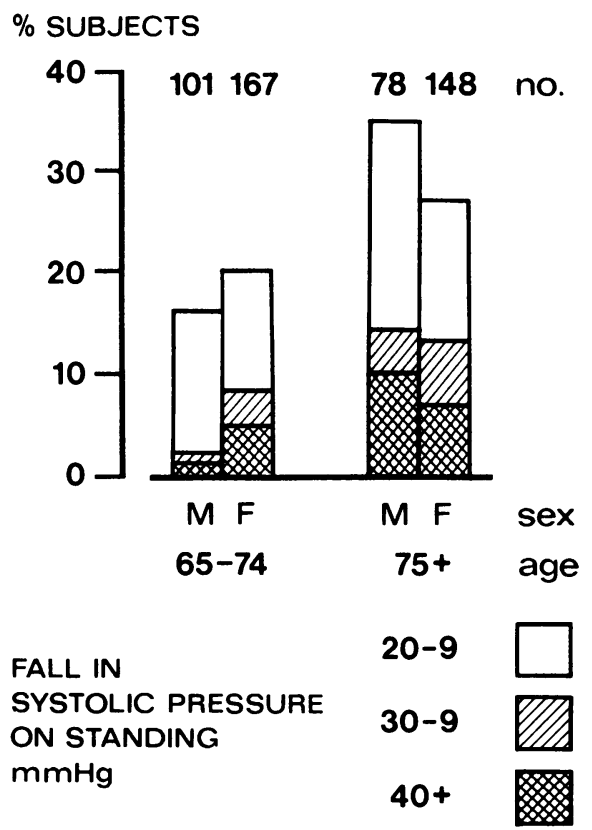

FIG. I Prevalence of fall in systolic pressure on standing (see Table $\mathrm{I}$ ).
For each subject whose systolic pressure fell by $20 \mathrm{mmHg}$ or more on standing, the next subject whose pressure did not fall by this amount was chosen from the same population, sex, and 5-year age group. Table 2 shows a comparison between these two matched groups of the frequency of organic brain disease, ischaemic or valvular heart disease, absence of ankle-jerks, presence of varicose veins, anaemia, urinary infection, serum sodium concentration of $137 \mathrm{mMol} / \mathrm{l}$. or less, and the taking of potentially hypotensive drugs. With the exception of organic brain disease and heart disease, each of

TABLE 2 Comparison between subjects with postural drop in systolic blood pressure and matched groups without

\begin{tabular}{|c|c|c|c|c|}
\hline \multirow[t]{2}{*}{ Systolic drop (mmHg) } & \multicolumn{2}{|c|}{$20+$} & \multicolumn{2}{|c|}{$30+$} \\
\hline & Yes & No & Yes & No \\
\hline Total no. & II6 & I16 & 46 & 46 \\
\hline \multicolumn{5}{|l|}{$\%$ with: } \\
\hline Organic brain disease & 8 & 17 & 7 & 20 \\
\hline Heart disease & 27 & 30 & 25 & 34 \\
\hline Absent ankle jerks & $3 \mathbf{I}$ & 27 & $4 \mathrm{I}$ & 27 \\
\hline Varicose veins & 30 & 24 & 35 & I7t \\
\hline \multicolumn{5}{|l|}{ Potentially hypo- } \\
\hline tensive drugs & 29 & 22 & 32 & 23 \\
\hline Anaemia & $18(5)$ & $14(5)$ & $14(2)$ & II (I) \\
\hline Urinary infection & 19 & $16(6)$ & 25 & 14 \\
\hline Hyponatraemia & IO (2) & $7(4)$ & $9(I)$ & $7(\mathrm{I})$ \\
\hline Combinations ${ }^{\star}$ & 4I & 29 & 50 & 17‡ \\
\hline
\end{tabular}

* Two or more of the following: absent ankle jerks, varicose veins, potentially hypotensive drugs, anaemia, urinary infection, hyponatraemia.

+ Difference significant at the 5 per cent level.

$¥$ Difference significant at the I per cent level.

Numbers in brackets are of subjects in whom the relevant observation was not made. 


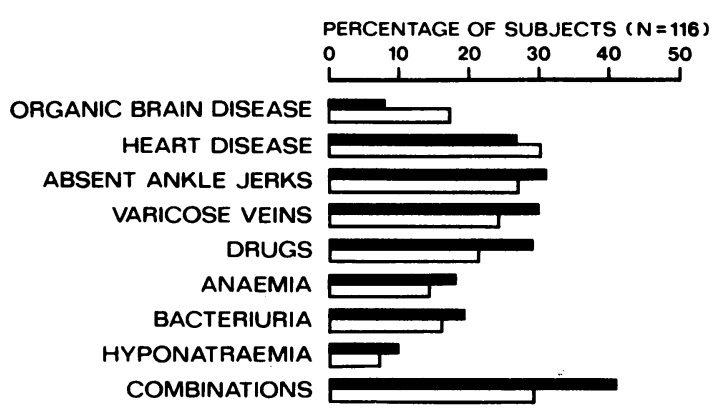

SYSTOLIC DROP $20+\mathbf{m m H g}$ $\square$ NO SYSTOLIC DROP

FIG. 2 Comparison between subjects with postural drop in systolic pressure of $20 \mathrm{mmHg}$ or more and matched group without (see Table 2).

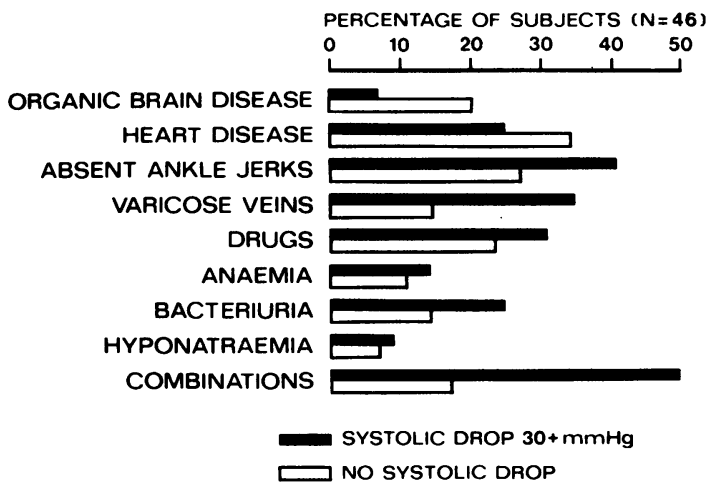

FIG. 3 Comparison between subjects with postural drop in systolic pressure of $30 \mathrm{mmHg}$ or more and matched group without (see Table 2).

these is more frequent in the group with a fall in systolic pressure than in that without, but the differences do not reach statistical significance in any instance (Fig. 2). Except for varicose veins, which are significantly more frequent in those with a fall in systolic pressure, the same is true if the comparison is made for those with a systolic drop of 30 $\mathrm{mmHg}$ or more (Fig. 3). But two or more of the five factors positively associated with a fall in pressure were present in $4 \mathrm{I}$ per cent of those with a fall of $20 \mathrm{mmHg}$ or more, and 50 per cent of those with a fall of $30 \mathrm{mmHg}$ or more. The corresponding frequencies in the control groups were 29 and 17 per cent, respectively. The difference for those with a drop of $30 \mathrm{mmHg}$ or more is statistically significant at the $\mathrm{I}$ per cent level.

\section{Discussion}

The two groups of old people studied in the present investigation are thought to be representative of old people living at home. The relatively high frequency of refusal to participate $(25 \%)$ is unlikely to have introduced significant bias, since the physical health (on superficial examination) of the Kilsyth subjects who refused to participate was good (Akhtar, 1972), and those who accepted and those who refused participation in a similar survey with a similar refusal rate have been shown not to differ in respect of many characteristics (Milne, Maule, and Williamson, I97I).

The present study confirms the high frequency of a fall in systolic blood pressure on standing in relatively healthy old people. The prevalence of a drop of $20 \mathrm{mmHg}$ or more ( $16 \%$ between ages 65 and 74 , and $30 \%$ over age 75 ) is higher than that found by others (11\%, Rodstein and Zeman, 1957; $17 \%$, Johnson et al., 1965), but differences in the age structures of the groups studied, and perhaps differences in the timing of the taking of the erect blood pressure may contribute. The prevalence of a larger drop of $40 \mathrm{mmHg}$ or more is very similar $(4-5 \%)$ in all three studies.

The analysis presented in Table 2 and Fig. 2 and 3 suggests that in old people living at home neither organic brain disease (Johnson et al., 1965; Gross, I970a) nor heart disease (in particular ischaemic heart disease) is associated with orthostatic hypotension. Several other factors are positively associated, but only in the case of varicose veins (and then only for a systolic drop of $30 \mathrm{mmHg}$ or more) is the association statistically significant. The more significant relation appears to be with combinations of factors. This suggests that in relatively healthy old people orthostatic hypotension usually has more than one contributory cause. Gross (1970b) has found evidence that impairment of circulatory reflexes, manifest as abnormality of the blood pressure response to Valsalva's manoeuvre (Johnson et al., 1965), increases in frequency with advancing age. The prevalence of such a disorder of autonomic function in the general elderly population is unknown, and cannot be determined from a clinical study such as this, but the frequency of orthostatic fall in blood pressure certainly increases with age (Table I; Fig. I). It may be that the autonomic disorder commonly interacts with another factor to produce symptomatic and overt orthostatic hypotension in old age.

Our thanks are due to the general practitioners in Kilsyth and northern Glasgow for permission to study their patients; to our colleagues in the surveys, in particular Drs. A. J. Akhtar, Anne Gilmore, and W. J. McLennan, 
Miss A. C. Crombie, S.R.N., and Miss J. MacDougall, S.R.N.; to Dr. R. H. Johnson for advice and criticism; and to the subjects for their willing co-operation. The surveys were supported by a grant from the Nuffield Provincial Hospitals Trust.

\section{References}

Akhtar, A. J. (1972). Refusal to participate in a survey of the elderly. Gerontologia Clinica. 14, 205.

Akhtar, A. J., Andrews, G. R., Caird, F. I., and Fallon, R. J. (1972). Urinary tract infection in the elderly: a population study. Age and Ageing, $1,48$.

Andrews, G. R., Cowan, N. R., and Anderson, W. F. (1971). The practice of geriatric medicine in the community. In Problems and Progress in Medical Care, p. 57. (Essays on Current Research, 5th Series.) Ed. by G. McLachlan. Oxford University Press, London.

Barraclough, M. A., and Sharpey-Schafer, E. P. (1963). Hypotension from absent circulatory reflexes: effects of alcohol, barbiturates, psychotherapeutic drugs, and other mechanisms. Lancet, I, 1121.

Fine, W. (1969). Some common factors in the causation of postural hypotension. Gerontologia Clinica, II, 206.
Gross, M. (1970a). The effect of posture on subjects with cerebrovascular disease. Quarterly fournal of Medicine, n.s. 39, 485 .

Gross, M. (1970b). Circulatory reflexes in cerebral ischaemia involving different vascular territories. Clinical Science, 38, 491.

Johnson, R. H., Smith, A. C., Spalding, J. M. K., and Wollner, L. (1965). Effect of posture on blood pressure in elderly patients. Lancet, $\mathbf{1}, 731$.

Kennedy, R. D., and Caird, F. I. (1972). Application of the Minnesota Code to population studies of the electrocardiogram in the elderly. Gerontologia Clinica, 14, 5.

Milne, J. S., Maule, M. M., and Williamson, J. (1971). Method of sampling in a study of older people with a comparison of respondents and non-respondents. British fournal of Preventive and Social Medicine, 25, 37.

Rodstein, M., and Zeman, F. D. (1957). Postural blood pressure changes in the elderly. Fournal of Chronic Diseases, 6, 581.

Rose, G. A., and Blackburn, H. (1968). Cardiovascular Survey Methods. W.H.O., Geneva.

Requests for reprints to Dr. F. I. Caird, University Department of Geriatric Medicine, Southern General Hospital, Glasgow G5I 4 TF. 